\title{
Effects of intravenous multiple busulfan injection on suppression of endogenous spermatogenesis in recipient stallion testes
}

\author{
Heejun Jung ${ }^{1}$ and Minjung Yoon ${ }^{1,2 *}$ \\ ${ }^{1}$ Department of Animal Science and Biotechnology, Kyungpook National University, Sangju 37224, \\ Korea \\ ${ }^{2}$ Department of Horse, Companion, and Wild Animal Science, Kyungpook National University, Sangju \\ 37224 , Korea
}

Received: May 7, 2021

Revised: Jun 1, 2021

Accepted: Jun 1, 2021

*Corresponding author

Minjung Yoon

Department of Horse, Companion, and Wild Animal Science, Kyungpook National University, Sangju 37224, Korea

Tel: +85-54-530-1233

E-mail: mjyoon@knu.ac.kr

Copyright $\odot 2021$ Korean Society of Animal Sciences and Technology. This is an Open Access article distributed under the terms of the Creative Commons Attribution Non-Commercial License (http:// creativecommons.org/licenses/by$\mathrm{nc} / 4.0 /$ ) which permits unrestricted non-commercial use, distribution, and reproduction in any medium, provided the original work is properly cited.

ORCID

Heejun Jung

https://orcid.org/0000-0001-9608-1412 Minjung Yoon

https://orcid.org/0000-0001-9112-1796

\section{Competing interests}

No potential conflict of interest relevant to this article was reported.

Funding sources

This work was supported by the Korea Institute of Planning and Evaluation for Technology in Food, Agriculture, Forestry and Fisheries (IPET) through the Advanced Production Technology Development Program, funded by the Ministry of Agriculture, Food and Rural Affairs (MAFRA) (114052-3).

\begin{abstract}
Preparation of recipient stallions is critical step to produce donor spermatogonial stem cell (SSC) derived sperm using transplantation technique. This study was conducted to evaluate the effects of intravenous busulfan infusion on germ cell depletion, semen production, and libido in stallions. Six Thoroughbred stallions were separated into two treatment groups: 1) a multiple low-dose ( $2.5 \mathrm{mg} / \mathrm{kg}$ bw for the first 4 weeks and $5 \mathrm{mg} / \mathrm{kg}$ bw for the 5 th week); and 2) control group treated with PBS. Testicular samples were obtained at 11 weeks and classified into three different patterns of spermatogenesis, such as normal, Sertoli cell only, and destroyed. Semen collection and libido experiments were performed 1 week before treatment, and 4 and 8 weeks after treatment. For the sperm analysis, total spermatozoa and motility were measured using a light microscope with a motility analyzing system. In the multiple lowdose group, the numbers of tubules categorized as Sertoli cell only were significantly higher than those in the control as well as the total population and total/progressive motility of sperm were significantly decreased 8 weeks after the start of the treatment. The sperm production and motility in the multiple low-dose group appears to be reduced, while libido was maintained. In conclusion, multiple administration of $2.5 \mathrm{mg} / \mathrm{kg}$ bw busulfan depletes endogenous germ cells in the stallion recipients for SSC transplantation.
\end{abstract}

Keywords: Busulfan, Germ cell depletion, Sperm, Stallion

\section{INTRODUCTION}

In 1994, offspring from infertile mice were successfully produced using the spermatogonial stem cell (SSC) transplantation technique [1], demonstrating that transplanted donor germ cells can colonize and differentiate into spermatozoa. Since then, SSC transplantation has been used to produce donorderived sperm in domestic animals including goats [2], pigs [3], rams [4], and dogs [5].

The preparation of SSC recipient animals is critical for improving the success rate of SSC transplantation. Because it improves the access of SSCs to the available niches in the seminiferous 
Acknowledgements

Authors would like to thank Dr. Buom-yong

Ryu at Chung-Ang University, and Dr. Hyuk

Song at Konkuk University for helpful advice

and input. Also, the authors would like to

thank Korea Racing Authority (KRA) for their

supports.

Availability of data and material

Upon reasonable request, the datasets

of this study can be available from the

corresponding author.

Authors' contributions

Conceptualization: Jung $\mathrm{H}$, Yoon $\mathrm{M}$.

Data curation: Jung $\mathrm{H}$, Yoon $\mathrm{M}$.

Formal analysis: Jung $\mathrm{H}$, Yoon $\mathrm{M}$.

Methodology: Jung $\mathrm{H}$, Yoon $\mathrm{M}$.

Software: Jung $\mathrm{H}$.

Validation: Jung $\mathrm{H}$, Yoon $\mathrm{M}$

Investigation: Jung $\mathrm{H}$.

Writing - original draft: Jung $\mathrm{H}$.

Writing - review \& editing: Jung $\mathrm{H}$, Yoon $\mathrm{M}$.

Ethics approval and consent to participate This study was performed at the research facility for domestic animals at Kyungpook National University. The protocol for animal use was approved by the Institutional Animal Care and Use Committee of Kyungpook National University (2017-0030). tubules of the testes. To prepare recipient animals, local glycerin injections [6-8], local irradiation $[9,10]$, or systemic busulfan injections $[1,11]$ have been used. Suppression of endogenous germ cells by a single intra-testicular injection of glycerin was first reported in Sprague-Dawley rats [8]. The study demonstrated that an intra-testicular injection of glycerin can be used to deplete endogenous germ cells to prepare recipients for transplantation. Recently, we reported that intra-testicular injection of $70 \%$ glycerin caused the disassociation of some germ cells in the seminiferous tubules of stallion testes, but did not fully deplete endogenous germ cells [7]. A technique to deplete germ cells within recipient mouse testes by local irradiation was also developed, resulting in $>95 \%$ empty tubules without apparent effects on Sertoli cells [12]. The irradiated mice were used as recipients in various mouse [12], rat [13], and bovine [14] transplantation studies. These studies indicated that donor-derived spermatogenesis can occur within round seminiferous tubules in which germ cells have been depleted by local irradiation. However, this approach requires the use of a costly and large machine, which is not universally available for use with stallions.

As an alternative to the local irradiation, busulfan has commonly been used as an alkylating agent and causes apoptosis of germ cells in the testes $[1,15,16]$. In a previous study, the use of an intraperitoneal injection of busulfan to deplete endogenous germ cells was evaluated in mice $[11,17]$; the use of busulfan in combination with chemotherapeutic drugs has also been reported $[15,18]$. However, busulfan has been shown to be toxic in domestic animals such as pigs [19] and dogs [20], inhibits hematopoiesis, and sometimes has lethal effects in rodents, owing to severe bone marrow depression. Therefore, an optimal safe dose and route of administration, for the use of busulfan treatment to deplete endogenous germ cells, should be determined in stallions.

The main objective of this study is to evaluate the effects of a multiple low-dose IV of busulfan on spermatogenesis, number and total / progressive motility of sperm comparing with the control group in stallions.

\section{MATERIALS AND METHODS}

\section{Animals}

This study was performed at the research facility for domestic animals at Kyungpook National University. The protocol for animal use was approved by the Institutional Animal Care and Use Committee of Kyungpook National University (2017-0030). Six Thoroughbred stallions were used in this study. The age of the stallions was $5.25 \pm 0.36$ years, ranging from 4 to 7 years. Stallions were individually stabled $(3 \times 4.5 \mathrm{~m})$ and rotationally turned out to the paddock $(20 \times 30 \mathrm{~m})$ for a day. Stallions were fed $1.5 \%$ of their body weight (bw) of Timothy hay (dry meter base) with $0.5 \%$ bw of commercial feed per day, and had access to water ad libitum during the experimental period. The stallions had no breeding history. The body conditioning score of stallions was between 4 and 5 throughout the whole research period. Stallions had no symptom of illness at the time of experiment.

\section{Experimental design}

The six Thoroughbred stallions were separated into two groups ( $\mathrm{n}=3$ /group). In group 1, $2.5 \mathrm{mg}$ / $\mathrm{kg}$ bw IV busulfan were administered to the stallions once per week for 4 weeks and $5 \mathrm{mg} / \mathrm{kg}$ bw IV busulfan for $5^{\text {th }}$ week, respectively. In group 2, the control group, a single IV dose of phosphatebuffered saline (PBS) was administered to the stallions. Prior to the study, all stallions were trained to mount and ejaculate on the dummy for semen collection once per week for 3-6 weeks. Semen was collected before treatment, and 4 and 8 weeks after busulfan treatment. Hemi-castration was performed 11 weeks after the initial busulfan treatment. 


\section{Busulfan infusion in stallions}

Busulfan ( $246.30 \mathrm{~g} / \mathrm{mol}$, Sigma-Aldrich, St. Louis, MO, USA) was administered by repeated weekly IV infusions of $2.5 \mathrm{mg} / \mathrm{kg}$ bw for the first 4 weeks and $5 \mathrm{mg} / \mathrm{kg}$ bw for the 5 th week. Busulfan was dissolved in dimethyl sulfoxide (99.7\%, Sigma-Aldrich) and sterilized using a $0.2 \mu \mathrm{m}$ syringe filter (Chromdisc, Daegu, Korea). A total of $40 \mathrm{~mL}$ of dissolved solution was loaded into 50 $\mathrm{mL}$ syringes (Buguang medical, Yangju, Korea). For infusion, a 16 gauge IV catheter $(1.7 \times 45 \mathrm{~mm}$, BD Biosciences, Franklin Lakes, NJ, USA) connected to an infusion set (Korea Vaccine, Ansan, Korea) was inserted into the jugular vein of the stallion. The $40 \mathrm{~mL}$ of solution was infused at 5 $\mathrm{mL} / \mathrm{min}$ using a fusion touch impregnator (Model Fusion 720, Chemyx, Stafford, TX, USA). After the infusion, the body condition, feeding, and behavior of the stallions were assessed.

\section{Testicular tissue analysis}

11 weeks after the first infusion of busulfan, hemi-castration for the analysis of testicular tissue has been performed. The testes were stored at $4{ }^{\circ} \mathrm{C}$ and used within 24 hours after the castration. For fixation, five pieces of testicular tissue were removed from three different sites, including the outside, middle, and inside of each testis, and were cut to $1 \mathrm{~cm}^{3}$ and immersed in $4 \%$ paraformaldehyde for at least $24 \mathrm{~h}$ with shaking gently at room temperature. To quantify the patterns of spermatogenesis in the cross-sections of the round seminiferous tubules, fixed testicular tissues were sliced and stained with hematoxylin and eosin. The morphological status of spermatogenesis was categorized into three different patterns: normal, Sertoli cell only, and abnormal spermatogenesis, following histological categorization previously used in the lab [7]. The ratio of testicular tissue categories was determined by counting 500 round seminiferous tubules from images captured at 100x and 200x magnifications using a Leica DMIL LED microscope (Leica, Wetzlar, Germany).

\section{Semen collection and assessment}

Semen was collected before treatment using the CSU Model ${ }^{\mathrm{TM}}$ Equine Artificial Vagina (Animal Reproduction Systems, Chino, CA, USA), and 1 week before busulfan treatment, and 4 and 8 weeks after treatment. The ejaculated semen was filtered through a disposable nylon mesh gel filter (Animal Reproduction Systems). After collection, the semen was diluted (1:20) with INRA96 extender (IMV Technologies, L'Aigle, France) pre-warmed to $37^{\circ} \mathrm{C}$. Total and progressive motility of spermatozoa was monitored using a light microscope (E200, Nikon, Tokyo, Japan) with a computer-assisted motility analyzing system (Sperm Class Analyzer 5.4, MICROPTIC, Barcelona, Spain). To determine the sperm concentration, ejaculated semen was fixed in $4 \%$ paraformaldehyde (Formalin 10 Equine semen diluent, Animal Reproduction Systems) at 1:20 dilution and counted using a hemocytometer (MARIENFELD, Laudakonigshofen, Germany) under 100x magnification using phase contrast microscopy (Nikon).

\section{Libido}

All stallions were monitored to assess the effect of busulfan treatment on sexual behaviors based on the following parameters: (1) time ( $\mathrm{min}$ ) to erection at the breeding area, (2) time (min) to ejaculation after the washing process, and (3) number of mounts on the dummy before successful ejaculation. For each stallion, the same environment was provided for behavior tests, and the same cycling mare was used to tease the stallions. The duration and frequency of each sexual behavior were observed and recorded.

\section{Statistical analysis}

Statistical analysis was performed using SPSS version 22 software (SPSS, Chicago, IL, USA). 
Statistical differences in spermatogenesis patterns were evaluated using a $t$-test. Results were considered statistically significant at $p$-values of $<0.05$. Data were expressed as the mean \pm SEM.

\section{RESULTS}

\section{Patterns of spermatogenesis}

Testicular tissue was stained with hematoxylin and eosin to assess the stages of spermatogenesis in a round cross-section of the seminiferous tubules. The spermatogenic status in the tubules was categorized as normal, Sertoli cell only, or abnormal (Fig. 1). Most of the seminiferous tubules ( 98.8
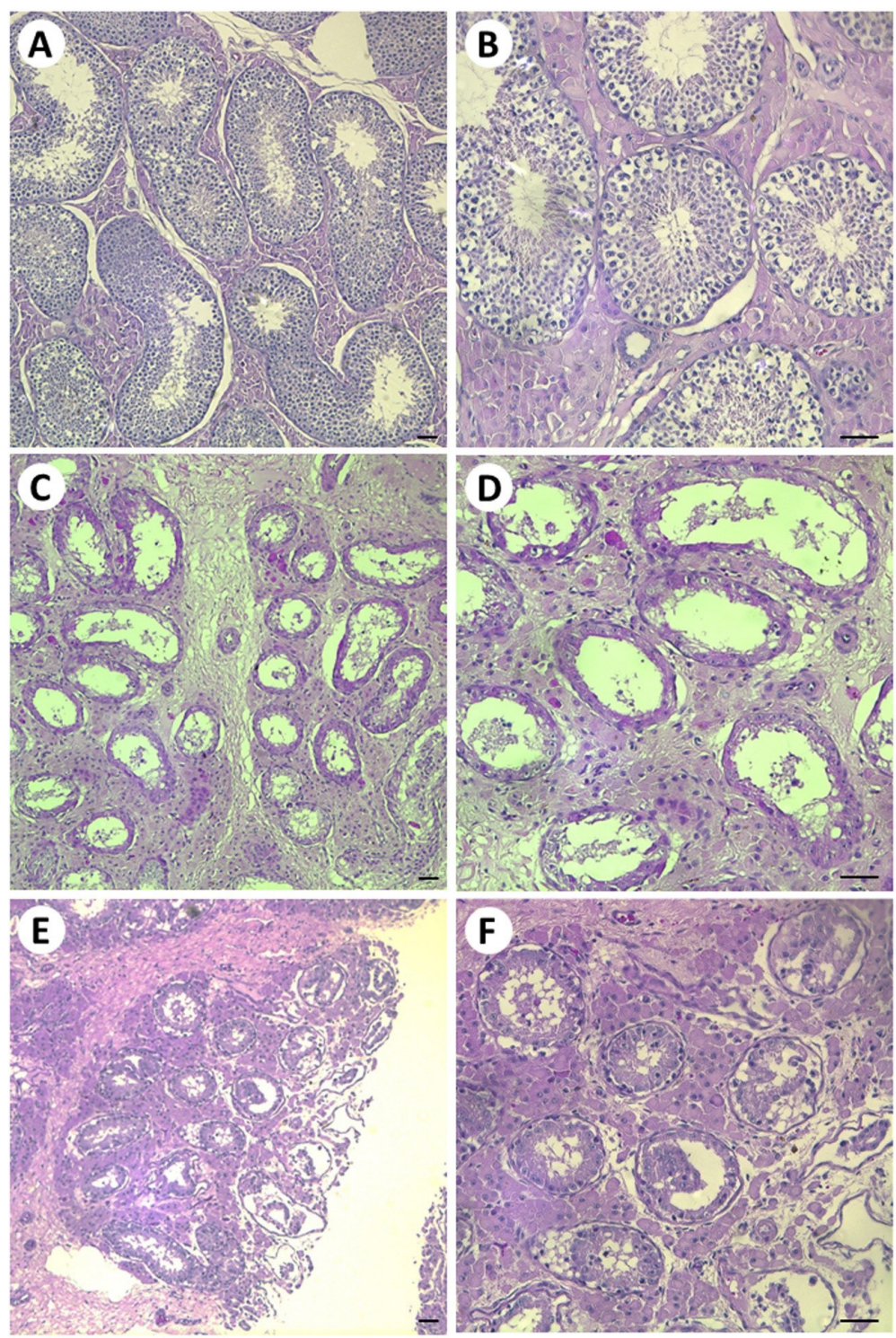

Fig. 1. Cross sections of seminiferous tubules of stallions treated with the multiple low-dose $(2.5 \mathrm{mg} /$ kg bw/week) IV busulfan injection. The three different patterns of spermatogenesis were classified as: (A and $B$ ) normal, ( $C$ and $D)$ Sertoli cell only, and ( $E$ and $F$ ) abnormal spermatogenesis, using H\&E staining. In normal spermatogenesis the seminiferous tubules were filled (A and B). In Sertoli cell only tubules, the round seminiferous tubules were hollowed without germ cells, but Sertoli cells were attached adjacent to the basement membrane ( $C$ and $D)$. In the abnormal spermatogenesis tubules, the germ cells were fragmented $(E$ and $F)$. Bar $=200 \mu \mathrm{M}$. H\&E, hematoxylin and eosin. 
$\pm 0.9 \%$ ) in the PBS treatment group was categorized as normal, indicating that PBS treatment did not affect spermatogenesis in the testes. However, the number of normal tubules was only $13.8 \pm$ $4.7 \%$ in the multiple low-dose group, and the number of Sertoli cell only tubules $(65.8 \pm 13 \%)$ was significantly higher $(p>0.05)$ than in the PBS group (0\%) (Table 1). Additionally, the proportion of tubules with abnormal spermatogenesis was higher in the multiple low-dose group $(20.3 \pm 8.8 \%)$ than in the PBS treatment group $(1.4 \pm 0.7 \%)$, but the difference was not significant $(p<0.05)$.

\section{Semen evaluation}

Semen evaluation was performed 1 week before busulfan treatment, and 4 and 8 weeks after treatment (Fig. 2). The number and total / progressive motility of sperm decreased in the multiple low-dose group compared with the control group using the sperm motility analyzing system based on computer-assisted semen analysis (CASA) program parameters (Table 2). At week 8, the number and total / progressive motility of sperm also appeared to decrease in the multiple dose group. However, statistical analysis was not performed because a stallion in this group refused to mount the dummy.

\section{Libido}

The sexual behaviors of the stallions were monitored to evaluate the effects of busulfan treatment on libido. The libido of stallions in both groups appears to be consistent with control group except one stallion in the multiple low-dose group. The statistical analysis was not performed due to one of stallions in the multiple dose group refused to mount the dummy. This stallion showed a similar behavior pattern prior to busulfan treatment.

Table 1. The ratio (\%) of each type of spermatogenesis pattern in cross section of round seminiferous tubules between PBS and multiple busulfan injection group

\begin{tabular}{|c|c|c|c|c|c|c|c|c|}
\hline \multirow{2}{*}{$\begin{array}{c}\text { Group } \\
\text { Horse ID }\end{array}$} & \multicolumn{4}{|c|}{ PBS } & \multicolumn{4}{|c|}{ Busulfan } \\
\hline & C1 & C2 & $\mathrm{C} 3$ & Mean \pm SEM & $\mathrm{T} 1$ & T2 & T3 & Mean \pm SEM \\
\hline Normal & 98.2 & 100 & 97.6 & $98.8 \pm 0.9^{\mathrm{a}}$ & 4.8 & 15.8 & 21 & $13.8 \pm 4.7^{b}$ \\
\hline Abnormal & 1.8 & 0 & 2.4 & $1.4 \pm 0.7^{\mathrm{a}}$ & 10 & 13 & 38 & $20.3 \pm 8.8^{\mathrm{a}}$ \\
\hline
\end{tabular}

,${ }^{a, b}$ Means with different superscript letters are significantly different $(p<0.05)$.

PBS, phosphate-buffered saline; $\mathrm{C}$, control; $\mathrm{T}$, treatment.

A

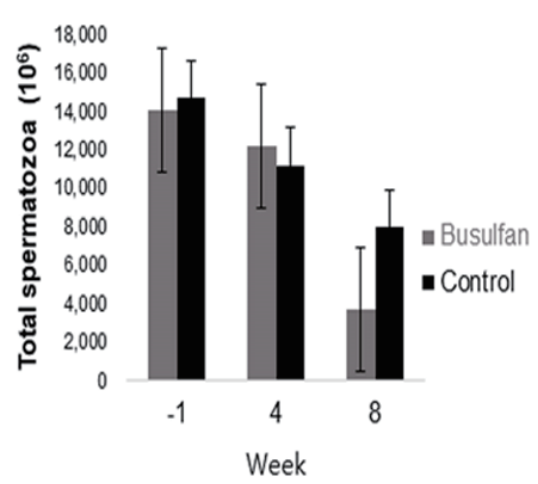

B

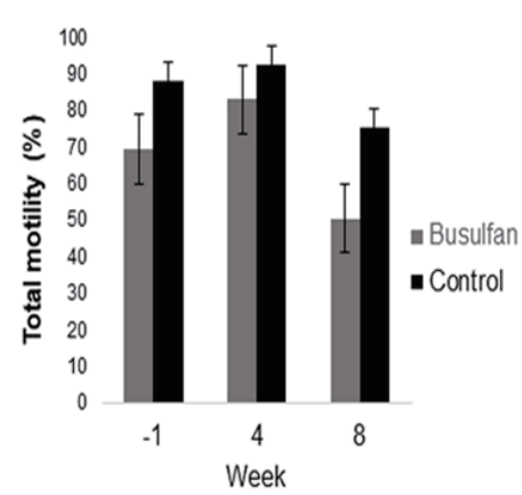

C

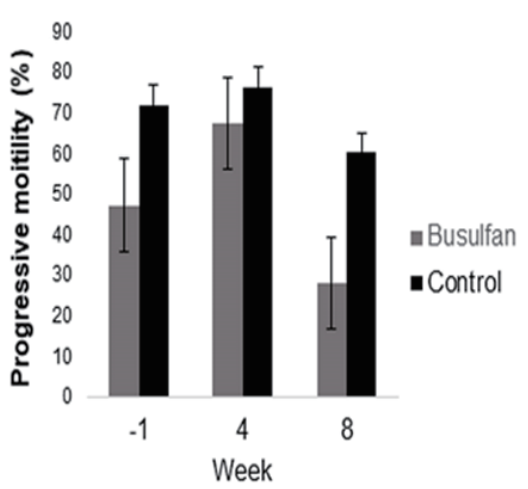

Fig. 2. The number and total / progressive motility of the sperm after busulfan treatment. (A) The number of spermatozoa tended to decrease at 4 and 8 weeks after busulfan treatment compared with the number before treatment (-1 week) and in the control group $(-1,4$, and 8 weeks). (B and C) After busulfan treatment the total / progressive motility of the sperm appears to be lower than that of the control group. No significant difference in semen parameters was found between groups. 
Table 2. Computer-assisted semen analysis (CASA) program setting

\begin{tabular}{lc}
\hline \multicolumn{1}{c}{ Parameter } & Setting \\
\hline Field-of-view depth=Depth of sample chamber & $20 \mu \mathrm{m}$ \\
Light adjustment & $90-105$ \\
Total number of cells evaluated or number of fields & 1,500 spermatozoa or 14 fields \\
Sperm recognition area & $15-75 \mu \mathrm{m}^{2}$ \\
Frame rate & 25 frames $/ \mathrm{sec}$ \\
Points assessed for sperm motility & 11, VAP points 5 \\
Total motility & Progressive motility + local motility \\
Local motility & DSL (distance: straight) $<6.0 \mu \mathrm{m}$ \\
Progressive motility & $>75 \%$ of STR (straightness) \\
\hline
\end{tabular}

\section{DISCUSSION}

In the present study, we investigated the effects of the multiple low dose IV infusion of busulfan to prepare recipient stallions for SSC transplantation. For the busulfan treatment, total concentration of the busulfan treatment has been determined as a $15 \mathrm{mg} / \mathrm{kg}$ bw, and the treatment was divided 5 times $(2.5 \mathrm{mg} / \mathrm{kg}$ for the first 4 weeks and $5 \mathrm{mg} / \mathrm{kg}$ bw for the 5 th week). Because the busulfan has been commonly known as an alkylating agent [15] and a single dose at high concentration such as 15 and $17.5 \mathrm{mg} / \mathrm{kg}$ bw can be occurred lethal effects due to inhibition of hematopoiesis and severe bone marrow depression [20]. In the previous study, two of four pigs injected with 15 $\mathrm{mg} / \mathrm{kg}$ bw busulfan died [19]. Similar adverse effects of busulfan treatment were reported in rhesus macaques [21]. In another study, one of each of two rhesus macaques treated with 8 and $12 \mathrm{mg} / \mathrm{kg}$ bw of busulfan survived for less than 10 and 7 weeks after treatment, respectively. These previous studies suggest that a single dose busulfan treatment at concentration at equal to or above $8 \mathrm{mg} / \mathrm{kg}$ bw causes high mortality across species. Hematopoietic parameters, such as complete blood count $(\mathrm{CBC})$, indicated that the rhesus macaques treated with 8 and $12 \mathrm{mg} / \mathrm{kg}$ bw of busulfan died from hematopoietic stem cell (HSC) depletion. We speculate based on previous studies that a single high dose of busulfan at a concentration of $15 \mathrm{mg} / \mathrm{kg}$ bw may cause toxic effects on the hematopoietic system in stallions. The treatment with a similar amount of busulfan with the multiple lowdose administration resulted in $100 \%$ survival of the stallions, indicating that the multiple lowdose method is much safer. Thus, it appears that treatment with $2.5 \mathrm{mg} / \mathrm{kg}$ bw busulfan does not completely deplete HSCs, although the treatment may have some detrimental effects on these cells. This speculation was determined based on a previous study that the HSCs survive for 10.5-11.5 days in mammals [22-24]. Thus, a 5 week treatment appears to be a sufficient amount of time for recovery of the cells lost following the earlier busulfan treatments. To support these speculative theories, additional evaluations should be performed to determine the justification of survival rate and side effects depending on of different concentrations of busulfan in further study.

The cavity of the round seminiferous tubules facilitates the migration and settlement of transplanted SSCs from the seminiferous lumen to the basement membrane $[25,26]$. Thus, a seminiferous tubule with Sertoli cells only, without germ cells, is ideal. In the present study, 11 weeks after the first of the weekly low-repeat dose infusions, $65.8 \%$ of the round sections of the seminiferous tubules contained Sertoli cells only, and were completely devoid of germ cells. The germ cells in the recipient stallions are depleted by busulfan, a DNA-alkylating agent that not only suppresses cell proliferation [27,28], but also causes cell apoptosis [29]. These results indicate that the multiple low-dose IV busulfan infusions may provide efficacious treatment for the preparation 
of recipient stallions. Interestingly, though confirmation for the presence of the Sertoli cells with a specific putative marker, such as GATA4 [30], was not performed in this study, unlike the empty spaces of the round seminiferous tubules were observed, the Sertoli cells that were attached to the basement membrane have histologically observed with hematoxylin and eosi (H\&E) staining. The busulfan preferentially damages DNA structure, prevents proliferation and differentiation of SSCs, and induces apoptosis [31]. The most common features of the SSCs are undergoing continuous self-renewal and differentiation to develop into mature sperm within the seminiferous tubules for the male lifetime [32]. In contrast, the Sertoli cells, also originally known as nurse cells, contribute to many stages of germ cell development for the completion of spermatogenesis [33], and they were determined as somatic cells [34]. Due to the Sertoli cells are not the stem cells, if the proliferation and differentiation process for maturity was fully progressed, further creation does not occur [35]. Thus, we speculate based on the previous results that the reason for the presence of the Sertoli cells could have retained from the detrimental effects of the busulfan treatment was that they discontinued the differentiation after full maturity.

A previous study in rhesus monkeys showed that sperm production sharply decreased after treatment with busulfan and reached a count of 0 at 10 weeks. In the present study, castration was performed 5 weeks after the last busulfan injection (11 weeks after the first injection). Therefore, the $20.3 \%$ of tubules with incomplete germ cell depletion (abnormal tubules) observed 5 weeks after the last busulfan injection may have contained germ cells undergoing depletion. Although this study was terminated 11 weeks after the first injection, we predict that more Sertoli cell only and fewer abnormal tubules would be present 11 weeks after the last busulfan injection (16 weeks after the first injection). At this time, the number of the Sertoli cell only (also known as the hollow state') seminiferous tubules should reach a maximum, because endogenous SSCs tend to regenerate and refill the tubules over time. Thus, it is hypothesized that the transplantation of germ cells should be performed no earlier than 11 weeks after the last busulfan injection.

One of the stallions in the multiple low-dose group failed to mount, although the erection response was normal. This stallion also exhibited this behavior before busulfan treatment, indicating that the failure in mounting the dummy was not associated with busulfan treatment. Because of this, a statistical comparison of semen parameters and libido could not be made between the multiple low-dose group and the control.

The effects of busulfan treatment on the total number of spermatozoa and total/progressive motility were evaluated. In the multiple low-dose group, the total number of spermatozoa decreased after busulfan treatment. This result is consistent with that of a previous study, in which IV injection of busulfan decreased sperm numbers in rhesus macaques; the sperm population was dramatically reduced 8 weeks after a $12 \mathrm{mg} / \mathrm{kg}$ bw IV injection of busulfan [21]. Busulfan is known to have a detrimental effect on differentiating spermatogonia $[27,36]$. Low total/progressive motility was also observed after low-repeat dose IV injection of busulfan. However, the main cause of low sperm motility was not assessed in this study. In a human study, an association between progressive motility impairment and sperm DNA damage was reported [37]. Alkylating agents such as busulfan interrupt DNA synthesis in cells [38]. Thus, the reduced sperm motility after busulfan treatment appears be a result of damage to the sperm DNA.

In conclusion, multiple low-dose treatments of busulfan at a concentration of $15 \mathrm{mg} / \mathrm{kg}$ bw is an optimal approach to treat stallion for the purpose of germ cell depletion. However, further study with higher number of stallions and additional experimental conditions should be performed to verify the optimal use of busulfan treatment for stallions. 


\section{REFERENCES}

1. Brinster RL, Avarbock MR. Germline transmission of donor haplotype following spermatogonial transplantation. Proc Natl Acad Sci USA. 1994;91:11303-7. https://doi.org/10.1073/ pnas.91.24.11303

2. Honaramooz A, Behboodi E, Blash S, Megee SO, Dobrinski I. Germ cell transplantation in goats. Mol Reprod Dev. 2003;64:422-8. https://doi.org/10.1002/mrd.10205

3. Dobrinski I. Germ cell transplantation in pigs--advances and applications. Soc Reprod Fertil Suppl. 2006;62:331-9.

4. Voglmayr JK, Waites GM, Setchell BP. Studies on spermatozoa and fluid collected directly from the testis of the conscious ram. Nature. 1966;210:861-3. https://doi. org $/ 10.1038 / 210861 \mathrm{~b} 0$

5. Kim Y, Turner D, Nelson J, Dobrinski I, McEntee M, Travis AJ. Production of donor-derived sperm after spermatogonial stem cell transplantation in the dog. Reproduction. 2008;136:82331. https://doi.org/10.1530/REP-08-0226

6. Igdoura SA, Wiebe JP. Suppression of spermatogenesis by low-level glycerol treatment. J Androl. 1994;15:234-43.

7. Jung $\mathrm{H}$, Yoon M. Effects of intratesticular injection of $70 \%$ glycerin on stallions. J Equine Vet Sci. 2017;49:1-10. https://doi.org/10.1016/j.jevs.2016.09.002

8. Wiebe JP, Barr KJ. The control of male fertility by 1,2,3-trihydroxypropane (THP; glycerol): rapid arrest of spermatogenesis without altering libido, accessory organs, gonadal steroidogenesis, and serum testosterone, LH and FSH. Contraception. 1984;29:291-302. https://doi. org/10.1016/S0010-7824(84)80009-8

9. Shuttlesworth GA, de Rooij DG, Huhtaniemi I, Reissmann T, Russell LD, Shetty G, et al. Enhancement of A spermatogonial proliferation and differentiation in irradiated rats by gonadotropin-releasing hormone antagonist administration. Endocrinology. 2000;141:37-49. https://doi.org/10.1210/endo.141.1.7272

10. van den Aardweg GJ, de Ruiter-Bootsma AL, Kramer MF, Davids JA. Growth and differentiation of spermatogenetic colonies in the mouse testis after irradiation with fission neutrons. Radiat Res. 1983;94:447-63. https://doi.org/10.2307/3575904

11. Brinster RL, Zimmermann JW. Spermatogenesis following male germ-cell transplantation. Proc Natl Acad Sci USA. 1994;91:11298-302. https://doi.org/10.1073/pnas.91.24.11298

12. Creemers LB, Meng X, den Ouden K, van Pelt AMM, Izadyar F, Santoro M, et al. Transplantation of germ cells from glial cell line-derived neurotrophic factor-overexpressing mice to host testes depleted of endogenous spermatogenesis by fractionated irradiation. Biol Reprod. 2002;66:1579-84. https://doi.org/10.1095/biolreprod66.6.1579

13. van Pelt AMM, Roepers-Gajadien HL, Gademan IS, Creemers LB, de Rooij DG, van Dissel-Emiliani FM. Establishment of cell lines with rat spermatogonial stem cell characteristics. Endocrinology. 2002;143:1845-50. https://doi.org/10.1210/endo.143.5.8806

14. Izadyar F, Matthijs-Rijsenbilt JJ, den Ouden K, Creemers LB, Woelders H, de Rooij DG. Development of a cryopreservation protocol for type A spermatogonia.J Androl. 2002;23:537-45.

15. Brinster CJ, Ryu BY, Avarbock MR, Karagenc L, Brinster RL, Orwig KE. Restoration of fertility by germ cell transplantation requires effective recipient preparation. Biol Reprod. 2003;69:412-20. https://doi.org/10.1095/biolreprod.103.016519

16. Moisan AE, Foster RA, Betteridge KJ, Hahnel AC. Dose-response of RAG2-/-/gammac-/- mice to busulfan in preparation for spermatogonial transplantation. Reproduction. 2003;126:205-16. https://doi.org/10.1530/rep.0.1260205 
17. Hermann BP, Sukhwani M, Winkler F, Pascarella JN, Peters KA, Sheng Y, et al. Spermatogonial stem cell transplantation into rhesus testes regenerates spermatogenesis producing functional sperm. Cell Stem Cell. 2012;11:715-26. https://doi.org/10.1016/j.stem.2012.07.017

18. Ogawa T, Arechaga JM, Avarbock MR, Brinster RL. Transplantation of testis germinal cells into mouse seminiferous tubules. Int J Dev Biol. 1997;41:111-22.

19. Honaramooz A, Behboodi E, Hausler CL, Blash S, Ayres S, Azuma C, et al. Depletion of endogenous germ cells in male pigs and goats in preparation for germ cell transplantation. J Androl. 2005;26:698-705. https://doi.org/10.2164/jandrol.05032

20. Hur TY, Lee SH, Ock SA, Song H, Park HJ, Lee R, et al. Dose-dependent effects of busulfan on dog testes in preparation for spermatogonial stem cell transplantation. Lab Anim Res. 2017;33:264-9. https://doi.org/10.5625/lar.2017.33.3.264

21. Hermann BP, Sukhwani M, Lin CC, Sheng Y, Tomko J, Rodriguez M, et al. Characterization, cryopreservation, and ablation of spermatogonial stem cells in adult rhesus macaques. Stem Cells. 2007;25:2330-8. https://doi.org/10.1634/stemcells.2007-0143

22. Gekas C, Dieterlen-Lievre F, Orkin SH, Mikkola HK. The placenta is a niche for hematopoietic stem cells. Dev Cell. 2005;8:365-75. https://doi.org/10.1016/j.devcel.2004.12.016

23. Kumaravelu P, Hook L, Morrison AM, Ure J, Zhao S, Zuyev S, et al. Quantitative developmental anatomy of definitive haematopoietic stem cells/long-term repopulating units (HSC/ RUs): role of the aorta-gonad-mesonephros (AGM) region and the yolk sac in colonisation of the mouse embryonic liver. Development. 2002;129:4891-9. https://doi.org/10.1242/ dev.129.21.4891

24. Medvinsky A, Dzierzak E. Definitive hematopoiesis is autonomously initiated by the AGM region. Cell. 1996;86:897-906. https://doi.org/10.1016/S0092-8674(00)80165-8

25. Ogawa T, Dobrinski I, Brinster RL. Recipient preparation is critical for spermatogonial transplantation in the rat. Tissue Cell. 1999;31:461-72. https://doi.org/10.1054/tice.1999.0060

26. Shinohara T, Orwig KE, Avarbock MR, Brinster RL. Remodeling of the postnatal mouse testis is accompanied by dramatic changes in stem cell number and niche accessibility. Proc Natl Acad Sci USA. 2001;98:6186-91. https://doi.org/10.1073/pnas.111158198

27. Bucci LR, Meistrich ML. Effects of busulfan on murine spermatogenesis: cytotoxicity, sterility, sperm abnormalities, and dominant lethal mutations. Mutat Res. 1987;176:259-68. https://doi. org/10.1016/0027-5107(87)90057-1

28. Iwamoto M, Nakaoka Y. External GTP binding and induction of cell division in starved Tetrahymena thermophila. Eur J Cell Biol. 2002;81:517-24. https://doi.org/10.1078/0171-933500267

29. Marcon L, Zhang X, Hales BF, Robaire B, Nagano MC. Effects of chemotherapeutic agents for testicular cancer on rat spermatogonial stem/progenitor cells. J Androl. 2011;32:432-43. https://doi.org/10.2164/jandrol.110.011601

30. Jung H, Roser JF, Yoon M. UTF1, a putative marker for spermatogonial stem cells in stallions. PLOS ONE. 2014;9:e108825. https://doi.org/10.1371/journal.pone.0108825

31. Iwamoto T, Hiraku Y, Oikawa S, Mizutani H, Kojima M, Kawanishi S. DNA intrastrand cross-link at the 5'-GA-3' sequence formed by busulfan and its role in the cytotoxic effect. Cancer Sci. 2004;95:454-8. https://doi.org/10.1111/j.1349-7006.2004.tb03231.x

32. de Kretser DM, Loveland KL, Meinhardt A, Simorangkir D, Wreford N. Spermatogenesis. Hum Reprod.1998;1:1-8. https://doi.org/10.1093/humrep/13.suppl_1.1

33. França LR, Hess RA, Dufour JM, Hofmann MC, Griswold MD. The Sertoli cell: one hundred fifty years of beauty and plasticity. Andrology. 2016;4:189-212. https://doi.org/10.1111/ andr.12165 
34. Griswold MD. The central role of Sertoli cells in spermatogenesis. Semin Cell Dev Biol. 1998;9:411-6. https://doi.org/10.1006/scdb.1998.0203

35. Sharpe RM, McKinnell C, Kivlin C, Fisher JS. Proliferation and functional maturation of Sertoli cells, and their relevance to disorders of testis function in adulthood. Reproduction. 2003;125:769-84. https://doi.org/10.1530/rep.0.1250769

36. Iwamoto M, Sugai T, Nakaoka Y. Cell division induced by mechanical stimulation in starved Tetrahymena thermophila: cell cycle without synthesis of macronuclear DNA. Cell Biol Int. 2004;28:503-9. https://doi.org/10.1016/j.cellbi.2004.04.004

37. Zini A, Phillips S, Lefebvre J, Baazeem A, Bissonnette F, Kadoch IJ, et al. Anti-sperm antibodies are not associated with sperm DNA damage: a prospective study of infertile men. J Reprod Immunol. 2010;85:205-8. https://doi.org/10.1016/j.jri.2010.03.006

38. Bignold LP. Alkylating agents and DNA polymerases. Anticancer Res. 2006;26:1327-36. 